\title{
Over Kanserini Taklit Eden Mycobacterium bovis Kaynaklı İntra-abdominal Tüberküloz Olgusu: Mikrobiyolojik Tanının Önemi
}

\section{A Case of Intra-abdominal Tuberculosis Due to Mycobacterium bovis Mimicking Ovarian Cancer: Importance of Microbiological Diagnosis}

\author{
Bahise Çağla TAȘKIN DALGIÇ ${ }^{1}$ (ID), Gülgün YENişEHIRLi²(ID), Elif Seren TANRIVERDi ${ }^{3}($ ID), \\ Murat AKKAN²(ID), Barış OTLU³(ID), Öznur SEZER ${ }^{4}(I D)$, Handan INÖNÜ KÖSEOĞLU4 ${ }^{4}(I D)$ \\ ${ }^{1}$ Tokat Turhal Devlet Hastanesi, Mikrobiyoloji Laboratuvarı, Tokat. \\ ${ }^{1}$ Tokat Turhal State Hospital, Microbiology Laboratory, Tokat, Turkey. \\ 2 Tokat Gaziosmanpaşa Üniversitesi Tıp Fakültesi, Tıbbi Mikrobiyoloji Anabilim Dalı, Tokat. \\ 2 Tokat Gaziosmanpaşa University Faculty of Medicine, Department of Medical Microbiology, Tokat, Turkey. \\ 3 İnönü Üniversitesi Tıp Fakültesi, Tıbbi Mikrobiyoloji Anabilim Dalı, Malatya. \\ 3 Inonu University Faculty of Medicine, Department of Medical Microbiology, Malatya, Turkey. \\ ${ }^{4}$ Tokat Gaziosmanpaşa Üniversitesi Tıp Fakültesi, Göğüs Hastalıkları Anabilim Dalı, Tokat. \\ ${ }^{4}$ Tokat Gaziosmanpaşa University Faculty of Medicine, Department of Chest Diseases, Tokat, Turkey.
}

\begin{abstract}
Makale Atıfı: Taşkın Dalgıç BÇ, Yenişehirli G, Tanriverdi ES, Akkan M, Otlu B, Sezer Ö ve ark. Over kanserini taklit eden Mycobacterium bovis kaynaklı intra-abdominal tüberküloz olgusu: Mikrobiyolojik tanının önemi. Mikrobiyol Bul 2022;56(1):124-132.
\end{abstract}

\section{ÖZ}

Mycobacterium bovis, çoğunlukla gelişmekte olan ülkelerde enfekte süt ve süt ürünlerinin tüketilmesi yoluyla bulaşarak gastrointestinal tüberküloza neden olmakta ve komşuluk yoluyla diğer intraabdominal doku ve organlara yayılabilmektedir. Abdominal tüberkülozlu kadın hastalarda kilo kaybı, halsizlik ve tutulum yerine göre karın ağrısı, kronik diyare gibi semptomların yanı sıra pelvik kitle, asit ve CA-125 yüksekliği gibi bulgulara rastlanabilmekte ve tanıda ilk olarak over kanseri akla gelmektedir. Tedavileri farklı olan bu iki hastalığın hızı bir şekilde birbirinden ayırt edilmesi oldukça önemlidir. Bu olgu raporunda, kilo kaybı, asit, pelvik kitle ve CA-125 yüksekliği gibi over kanser bulgularını taklit eden, tanısı mikrobiyolojik yöntemlerle kesinleşmiş M.bovis kaynaklı intra-abdominal tüberküloz olgusu sunulmuştur. Karın ağrısı, kilo kaybı, asit, pelvik kitle ve CA-125 yüksekliği $(643.9 \mathrm{U} / \mathrm{ml}$ ) bulguları olan, abdomen bilgisayarlı tomografi (BT)'sinde sol tubaovaryan bölgede kitle tespit edilen yirmi üç yaşında kadın hastaya kolonoskopi yapılmıştır. İleum biyopsi örneği ve parasentez ile alınan asit sıvı örneği, aside dirençli boyama (ARB) ile direkt mikroskopik inceleme ve tüberküloz kültürü yapılması amacıyla laboratuvarımıza gönderilmiştir. Laboratuvarımızda örnekler hem sIVı [BACTEC MGIT 320 Mycobacteria Kültür Sistemi (Becton Dickinson, ABD)] hem de katı [Löwenstein-Jensen besiyeri (Becton Dickinson, $A B D)$ ] kültür ortamında inkübe edilmiş ve ARB yaymaları yapılmıştır. ARB yaymaları negatif olarak saptanırken, sıvı kültür ortamında ileum biyopsi materyali 14. günde, asit sıvı örneği 11. günde üreme sinyali vermiştir. Sıvı kültür şşşesinden yapılan ARB boyamada kord faktörü oluşmuş, mavi zemin üzerinde kırmızı basiller görülmüştür. İzolat immünkromatografik hızlı test BD MGIT TBC Identification 
Test (BD, $\mathrm{ABD}$ ) ile Mycobacterium tuberculosis kompleks olarak tanımlanmıştır. Hastaya intra-abdominal tüberküloz tanısıyla tam doz anti-tüberküloz tedavi başlanmıştır. Antibiyotik duyarlılık sonuçlarına göre izolat izoniazid, rifampisin, etambutol duyarlı, streptomisin dirençli olarak bulunmuştur. M.tuberculosis kompleksin alt tür tanımlanması, "matrix-assisted laser desorption ionization-time of flight mass spectrometry (MALDI-TOF MS)" yöntemiyle araştııılmış ancak alt tür tanımlaması yapılamamıştır. İzolat, GenoType MTBC VER 1.X (Hain Lifescience, HardwiesenstraBe, Almanya) kiti ile genotiplendirilmiş ve M.bovis olarak tanımlanmıştır. Hastanın üç ay sonraki kontrolünde tümör belirteçleri asit sıvısı ve intra-abdominal lenf nodlarının belirgin şekilde gerilediği ve sol overdeki kitlenin tamamen kaybolduğu tespit edilmiştir. Over kanserinin klinik, radyolojik ve laboratuvar bulgularını taklit eden intra-abdominal tüberküloz olgusunun sunulduğu bu raporda mikrobiyolojik tanının önemini vurgulamak amaçlanmıştır.

Anahtar kelimeler: Intra-abdominal tüberküloz; over kanseri; Mycobacterium bovis.

\section{ABSTRACT}

Mycobacterium bovis causes gastrointestinal tuberculosis by being transmitted through consumption of infected milk and dairy products, mostly in developing countries, and can spread to the other neighbourhood intra-abdominal tissues and organs. In addition to the symptoms such as weight loss, weakness, abdominal pain, and chronic diarrhea in female patients with abdominal tuberculosis, findings such as pelvic mass, ascites and CA-125 elevation may be encountered. Patients with these symptoms usually preliminary diagnosed as having ovarian cancer. It is very important to distinguish between these two diseases quickly, which have different treatment protocols. In this case report, a case of intra-abdominal tuberculosis caused by M.bovis, whose diagnosis was confirmed by microbiological methods with the findings mimicking ovarian cancer such as weight loss, ascites, pelvic mass and increased CA-125 was presented. Tuberculosis was considered in the differential diagnosis of a 23-yearold female patient with abdominal pain, weight loss, ascites, pelvic mass, and elevated CA-125 (643.9 $\mathrm{U} / \mathrm{ml}$ ) findings and a mass in the left tubaovarian region on abdominal CT. The ileum biopsy sample taken during colonoscopy and ascitic fluid sample taken with paracentesis were sent to our laboratory for acid-fast bacilli (AFB) staining and tuberculosis culture. In our laboratory, samples were incubated in both liquid culture system [BACTEC MGIT 320 Mycobacteria Culture System (Becton Dickinson,USA)] and solid culture medium [Lowenstein-Jensen Medium (Becton Dickinson,USA)] and AFB smears were performed. While AFB smears were negative, ileum biopsy material showed growth on day 14 and ascitic fluid sample on day 11 in liquid culture medium. AFB smear was prepared from broth and red bacilli were seen on a blue background that formed cord factor. The bacillus was identified as Mycobacterium tuberculosis complex by the immunochromatographic rapid test [BD MGIT TBC Identification Test $(B D, U S A)]$. The anti-tuberculosis drug treatment was initiated with the diagnosis of intra-abdominal tuberculosis. The isolated bacillus was found to be sensitive to isoniazid, rifampicin, ethambutol and resistant to streptomycin, according the drug susceptibility test results. Subspecies identification of M.tuberculosis complex was investigated by matrix-assisted laser desorption ionization-time of flight mass spectrometry (MALDI-TOF MS) but could not be determined by this method. Genotyping was performed with the GenoType MTBC VER 1.X (Hain Lifescience, HardwiesenstraBe, Germany) kit. The isolate was identified as M.bovis. In the follow-up of the patient three months later, it was determined that tumor markers, ascitic fluid and intra-abdominal lymph nodes regressed significantly and the mass in the left ovary completely disappeared. In this report, we presented a case with intra-abdominal tuberculosis whose clinical, radiological and laboratory findings mimic ovarian cancer to imply the importance of microbiological diagnosis.

Keywords: Intra-abdominal tuberculosis; ovarian cancer; Mycobacterium bovis.

\section{Giriş}

Tüberküloz; Mycobacterium tuberculosis kompleks (MTBC)'in neden olduğu, tipik olarak akciğerleri tutan ancak akciğer dışı pek çok doku ve organı da etkileyebilen bir enfeksiyon hastalığıdır. Tüberküloz, tek bir bulaşıcı ajandan kaynaklanan ölümlerin önde 
gelen nedenidir ve dünya çapında ölüm nedenleri arasında ilk 10'da yer alan önemli bir halk sağlığı sorunudur ${ }^{1}$. 2020 yılı Küresel Tüberküloz Raporunda 2019 yılında 10 milyon kişinin tüberküloz hastası olduğu ve 1.4 milyon kişinin tüberkülozdan hayatını kaybettiği bildirilmiştir ${ }^{1}$.

Mycobacterium bovis, hem hayvanları hem de insanları enfekte edebilen geniş konak aralığına sahip bir MTBC üyesidir. M.bovis'in insanlar için en önemli bulaş kaynağı kontamine ve pastörize edilmemiş süt tüketimidir. Bunun yanında enfekte hayvanlar ile direkt temas veya hasta hayvanların çıkarttığı enfeksiyöz aerosollerin inhalasyonu ile de bulaş mümkündür² ${ }^{2}$ Böylece hem akciğer hem de akciğer dışı tüberküloza (ADTB) neden olmaktadır.

Akciğer dışı tüberküloz, primer enfeksiyonun lenfohematojen ya da komşuluk yoluyla diğer organlara yayılması veya latent kalan tüberküloz basilinin reaktive olmasıyla gelişmektedir. Akciğer dışı tüberküloz, ülkemizde tüm hastaların yaklaşık \%35'inde görülmektedir ${ }^{3}$. Ülkemizde ADTB'de ilk sıralarda plevra tüberkülozu yer alırken, periton/gastrointestinal sistem tüberkülozu dördüncü sırada yer almaktadır ${ }^{3}$. Abdominal tüberküloz periton, lenf bezi, ince bağırsak, kolon, mide ve diğer karın içi organların tüberkülozu şeklinde değişik formlarda gözlenebilir ${ }^{4}$.

Abdominal tüberkülozlu hastalarda kilo kaybı, halsizlik ve tutulum yerine göre karın ağrısı, kronik diyare gibi semptomlar görülmektedir ${ }^{3}$. Bununla birlikte kadın hastalarda pelvik kitle, asit ve CA-125 yüksekliği gibi bulgulara da rastlanmakta ve ilk olarak over kanseri akla gelmektedir ${ }^{5}$. Bu nedenle tedavileri farklı olan bu iki durumun en kısa sürede birbirinden ayırt edilmesi çok önemlidir. Tedavide gecikme, morbidite ve mortalitede artış nedenidir6

Bu makalede, kilo kaybı, asit, pelvik kitle ve CA-125 yüksekliği gibi over kanserini taklit eden bulguları olan, tanısı mikrobiyolojik yöntemlerle kesinleşmiş M.bovis kaynaklı intra-abdominal tüberküloz olgusu sunulmuştur.

\section{OLGU SUNUMU}

Yirmi üç yaşında kadın hasta 3-4 aydır devam eden karın ağrısı, bulantı, kusma, halsizlik, son altı ayda $20 \mathrm{~kg}$ kilo kaybı şikayetleriyle dahiliye polikliniğine başvurdu. Hastanın anamnezi derinleştirildiğinde iki aydır eforla artan nefes darlığı, gece terlemesi, karında şişlik ve kanlı gaita yapma gibi yakınmaları da mevcuttu. Öz geçmiş ve soy geçmişinde özellik olmayan hastanın fizik muayenesinde bilateral akciğer sesleri azalıp, batında yaygın asit ve sağ alt kadranda hassasiyeti olduğu görüldü. Hastanın hayvancılıkla uğraştığı ve pastörize edilmemiş süt ve süt ürünleri tüketimi öyküsünün olduğu öğrenildi. Kan değerlerinde hemoglobin (Hb) düzeyi $11.1 \mathrm{gr} / \mathrm{dl}$ ve ortalama eritrosit hacmi (MCV) $69.3 \mathrm{fl}$ olan hastanın bulguları demir eksikliği anemisi ile uyumluydu. Sedimantasyon düzeyi $57 \mathrm{~mm} / \mathrm{saat}$ (20 mm/saat) ve C-Reaktif protein (CRP) $47.39 \mathrm{mg} / \mathrm{L}$ (0-5 mg/L) idi.

Hastanın toraks bilgisayarlı tomografi (BT)'sinde bilateral plevral efüzyonu mevcuttu ve akciğer parankimi normaldi. Abdomen $\mathrm{BT}^{\prime}$ sinde sol tubo-ovariyan alandan başlaya- 
rak pelvis anterioruna uzanan, en geniş yerinde $10 \times 8 \times 7 \mathrm{~cm}$ boyutlara ulaşan kistik ve kontrastlanan solid alanlar barındıran kalın duvarlı kitle lezyonu ve pelviste minimal sıvı mevcuttu. Peritoneal yapraklar kalınlaşmış görünümde ve sol paraaortik alanda renal ven inferiorunda multipl lenfadenopatiler izlendi.

Hastanın tümör belirteçleri CA-15-3, $61.41 \mathrm{U} / \mathrm{ml}(0-25 \mathrm{U} / \mathrm{ml})$ ve CA-125 $643.9 \mathrm{U} / \mathrm{ml}$ (0-35 U/ml) değerleri ile yüksek tespit edildi. Parasentez ile alınan asit sıvısında glukoz $6.1 \mathrm{mg} / \mathrm{dl}$, albümin $3.21 \mathrm{gr} / \mathrm{dl}$, total protein $7.52 \mathrm{gr} / \mathrm{dl}, \mathrm{LDH} 1625 \mathrm{U} / \mathrm{L}$, eş zamanlı serumda albümin $3.47 \mathrm{gr} / \mathrm{dl}$, total protein $7.67 \mathrm{gr} / \mathrm{dl}, \mathrm{LDH} 207 \mathrm{U} / \mathrm{L}$ idi ve asit sıvısı eksuda vasfındaydı.

Kolonoskopide terminal ileumda $2-3 \mathrm{~cm}$ düzensiz sınırlı ülser görülen hastanın ileal biyopsi materyali ve parasentez sırasında alınan asit sıvısı, aside dirençli boyama (ARB) ve tüberküloz kültürü için laboratuvarımıza gönderildi. Tüberküloz polimeraz zincir reaksiyonu (PCR) test istemi mevcut değildi.

Laboratuvarımızda ileal biyopsi materyali homojenizasyon ve konsantrasyon; asit sıVISI ise konsantrasyon ön işlemlerine tabi tutulduktan sonra BACTEC MGIT 320 Mycobacteria Kültür Sistemi (Becton Dickinson, $\mathrm{ABD}$ ) sıvı kültür sistemi ve gliserollü Löwenstein-Jensen besiyeri (Becton Dickinson, $A B D$ ) katı kültür sisteminde inkübe edildi ve ARB yapıldı. Hem ileal biyopsi örneğinin hem de asit sıvısının yaymasında aside dirençli basil görülmedi. İleum biyopsi örneğinin patolojik incelemesi özgül olmayan kronik enflamasyon olarak raporlandı.

Hastanın biyopsi materyali kültürü 14. günde, asit sıvısı kültürü ise 11. günde üreme sinyali verdi. Sıvı kültür şişesinden yapılan ARB boyamada kord faktör oluşturmuş, mavi zemin üzerinde kırmızı basiller görüldü. İmmünkromatografik hızlı test BD MGIT TBC Identification Test (BD, ABD) ile izolat MTBC olarak tanımlandı. Hastanın takibini yapan göğüs hastalıkları hekimi aranarak bilgi verildi. Vücut ağırlığı 55 kg olan hastaya intraabdominal tüberküloz tanısıyla tam doz anti-tüberküloz tedavi [izoniazid (INH) $1 \times 300$ mg, rifampisin (RIF) $1 \times 600$ mg, etambutol (ETM) $1 \times 1500$ mg, pirazinamid (PZA) 1 x $2000 \mathrm{mg}]$ ) başlandı.

Birinci seçenek ilaçlar (INH, ETM, RIF, streptomisin) için BACTEC MGIT 320 Mycobacteria Kültür Sistemi (BD, ABD) cihazı ile duyarlılık testleri yapıldı. Antibiyotik duyarıııı sonuçlarında izolat INH, RIF, ETM duyarlı, streptomisin dirençli olarak bulundu. Laboratuvarımızda PZA duyarılığı bakılamadığı için sonuç bildirilemedi. Hastanın antibiyoterapisi iki ay dörtlü (INH, RIF, ETM, PZA), dört ay ikili (INH, RIF) olacak şekilde planlandı.

Her iki örneğin katı kültüründe 30. günde pigmentsiz, düzensiz, kuru, krem rengi koloniler oluştuğu görüldü. MTBC'nin alt tür tayini, basilin katı kültürde üremesi gerçekleştikten sonra öncelikle "matrix-assisted laser desorption ionization-time of flight mass spectrometry (MALDI-TOF MS)" yöntemiyle araştırıldı. Mikobakterinin protein ekstraksiyonu VITEK MS Mycobacterium/Nocardia örnek hazırlama kiti (Bio Merieux, Fransa) kullanılarak yapıldı. Elde edilen süpernatandan $1 \mu$ l alınarak MALDI-TOF hedef plakası 
üzerindeki bir noktaya pipetlendi. Ayrı bir noktaya $1 \mu$ l kalibrasyon standardı pipetlendi. Örnek kuruduktan sonra günlük hazırlanan MALDI matriksinden $2 \mu$ numuneye ve kalibrasyon standardına pipetlendi. Örnek kuruduktan sonra VITEK MS MALDI-TOF MS (Bio Merieux, Fransa) cihazında tanımlamaya alındı. Elde edilen spektrumlar üreticinin veri tabanındakilerle eşleştirildi. İzolat bu yöntemle MTBC olarak tanımlandı. Bu yöntemle alt tür tayini yapılamadı.

Daha sonra alt tür tayini için GenoType MTBC VER 1.X (Hain Lifescience, HardwiesenstraBe, Almanya) kiti ile genotiplendirme yapıldı. Bu işlem üç aşamalı bir prosedür ile gerçekleştirildi: i) DNA QIAGEN EZ1 Advanced XL (QIAGEN, Almanya) ile ekstrakte edildi. ii) Üreticinin önerileri doğrultusunda PCR reaksiyon karışımı ve amplifikasyon protokolü uygulandı. iii) Amplifikasyon ürünlerinin ters hibridizasyonu GenoType MTBC test şeritleri ve firma cihazı TwinCubator (HainLifescience, Nehren, Almanya) kullanılarak yapıldı.

Son yıkamadan sonra, MTBC şeritleri havada kurutuldu ve kağıt üzerine sabitlendi. Amplifikasyon ve hibridizasyon kontrolleri, test prosedürlerini doğruladı; bir MTBC kontrolü, tanımlamayı MTBC olarak doğruladı. Test sonuçlarının yorumlanması için her ikisi de kit ile birlikte verilen çizgilerin konumlarını gösteren bir şablon sayfası ve yorumlama tablosu kullanıldı. İzolat M.bovis olarak tanımlandı. İzolatın alt tür tayini kesinleştiğinde hasta idame tedavi içinde olduğu için tedavide değişikliğe gidilmedi.

Hastanın kontrollerinde bulantı, kusma, karın ağrısı, iştahsızlık şikayetlerinin gerilediği ve kilo aldığı görüldü. CA-125, anti-tüberküloz tedaviden sonraki 15. günde $459 \mathrm{U} / \mathrm{ml}$, birinci ayda $185 \mathrm{U} / \mathrm{ml}$, üçüncü ayda $88 \mathrm{U} / \mathrm{ml}$ ve altıncı ayda (tedavi bitimi) $73.02 \mathrm{U} /$ $\mathrm{ml}$ ile belirgin bir düşme gösterdi. Aynı şekilde CA-15-3'ün, $65.69 \mathrm{U} / \mathrm{ml}, 44.35 \mathrm{U} / \mathrm{ml}$ ve $29.7 \mathrm{U} / \mathrm{ml}$ ve tedavi bitiminde 17.94 değerleriyle normale döndüğü görüldü. Hastanın CRP (33 mg/L, $11.06 \mathrm{mg} / \mathrm{L}, 20.4 \mathrm{mg} / \mathrm{L}, 8 \mathrm{mg} / \mathrm{L}, 5.65 \mathrm{mg} / \mathrm{L}, 4.37 \mathrm{mg} / \mathrm{L}$ )'si ve sedimantasyon değerleri de (43 mm/saat, $22 \mathrm{~mm} / \mathrm{saat}, 19 \mathrm{~mm} / \mathrm{saat}, 13 \mathrm{~mm} / \mathrm{saat}$ ) tedaviyle normale döndü. Tedavinin üçüncü ayı tamamlandığında yapılan kontrol abdomen BT tetkiki, tedavi öncesi BT ile karşılaştırıldığında peritoneal kalınlaşmanın boyut ve sayısında, intra-abdominal lenfadenopatilerin boyut, sayı ve görünümlerinde belirgin gerileme izlenirken, sol overdeki lezyonun tamamen kaybolduğu tespit edildi.

\section{TARTIŞMA}

Abdominal tüberküloz, gastrointestinal sistem, periton, lenf düğümleri ve solid iç organları tutabilen, en sık periton ve abdominal lenf nodlarında yerleşim gösteren tüberküloz türüdür. Abdominal tüberküloz gelişmekte olan ülkelerde çoğunlukla M.bovis kaynaklı enfekte süt ve süt ürünlerinin tüketilmesi ile bulaşmakta ve komşuluk yoluyla diğer intra-abdominal doku ve organlara yayılabilmektedir. Ayrıca primer akciğer odağından lenfohematojen yolla yayılım da mümkündür ${ }^{7}$. Koç ve arkadaşlarının 22 olguyu inceledikleri peritoneal tüberküloz olgu serisinin ${ }^{5}$ yalnızca ikisinde primer lezyona ait bulgu saptamışlardır. Olgumuzda periton ve ileum tutulumu mikrobiyolojik olarak gösterilmiş- 
tir. Tüberküloz etkeninin M.bovis olması ve hastanın öyküsünde pastörize edilmemiş süt ve süt ürünleri tüketimi öyküsü olması nedeniyle olgumuz gastrointestinal tüberkülozun yakın doku ve organlara yayılımı şeklinde yorumlanmıştır. Toraks BT'de akciğer parankimi normal olan hastada primer akciğer tüberkülozu düşünülmemiştir. Tomografide tespit edilen bilateral plevral efüzyonun, batın içindeki asit sıvısının transdiyafragmatik geçişine bağlı olduğu düşünülmüştür.

Abdominal tüberkülozun klinik spektrumu oldukça geniştir ve özgül değildir ${ }^{7}$. Olgumuzda karın ağrısı, bulantı, kusma, kilo kaybı, kanlı gaita yapma ve karında hassasiyet semptom ve bulguları mevcuttu. Sanai ve arkadaşlarının derlemesinde ${ }^{8}$ tüberküloz peritonitli olguların kliniğe başvurularında \%73 asit, \%64.5 karın ağrısı, \%61 kilo kaybı, \%59 ateş ve \%47.7 karında hassasiyet bulgularının olduğu bildirilmiştir.

Klinik, radyolojik ve laboratuvar bulgularının benzerliği nedeniyle abdominal tüberküloz over kanseri ve peritoneal karsinomatozisi taklit edebilmektedir. Ultrasonografi, tomografi ve manyetik rezonans inceleme gibi görüntüleme yöntemleri ayırıcı tanıya yardımcı olabilir. Rodriguez ve arkadaşlarının tüberküloz peritonit ve peritoneal karsinomatozun BT bulgularını karşılaştırdıkları çalışmada ${ }^{9}$, her iki durumda da batında asit varlığını gösterilmiş, tüberküloz peritonitte peritonda hafif düz kalınlaşma, peritoneal karsinomatoziste ise peritonda düzensiz kalınlaşma tespit edilmiştir. Wang ve arkadaşlarının over kanserini taklit eden peritoneal tüberkülozlu 26 olgunun yer aldığı seri çalışmalarında ${ }^{10}$, altı olguda peritoneal kalınlaşma, üç olguda tek taraflı, sekiz olguda bilateral adneksiyal kitle ve beş vakada lenfadenopati tespit edilmiştir. Olgumuzun abdomen BT'sinde sol tubo-ovariyan alandan başlayarak pelvis anterioruna uzanım gösteren en geniş yerinde $10 \times 8 \times 7 \mathrm{~cm}$ boyutlara ulaşan kistik ve kontrastlanan solid alanlar barındıran kalın duvarlı kitle lezyon mevcut bulunmuştur. Peritoneal yapraklar kalınlaşmış görünümde, batın içinde yağ planları arasında çok sayıda peritoneal implant ile uyumlu yumuşak doku lezyonları ve sol paraaortik alanda renal ven inferiorunda multipl lenfadenopatiler izlenmiştir.

CA-125 düzeyi, over karsinomu, bazı genital sistem dışı kanserlerde yüksek değerde tespit edilmekte ve epitelyal over kanseri olan hastaların izlenmesi için kullanılmaktadır. Yapılan çalışmalar CA-125 düzeyinin tüberküloz peritonit hastalarında da belirgin olarak yükseldiğini ve uygun tedavi sonrası gerileme olduğunu göstermektedir ${ }^{10-12}$. Bu olguda da, ilk başvuruda serum CA-125 seviyeleri normal sınırların üzerinde bulunmuş ve antitüberküloz tedaviyle gerileme göstermiştir.

Sunulan olguda kanıtlandığı gibi, klinik, radyolojik ve CA-125 yüksekliği ile over kanserini düşündüren hastaların ayırıcı tanısında tüberkülozun düşünülmesi, uygun örneklerin mikrobiyolojik açıdan değerlendirilmesi için laboratuvara gönderilmesi ve tanının hızlı bir şekilde konulup, hastanın uygun tedaviyi hızla alması ve gereksiz cerrahi girişimin önlenmesi son derece önemlidir. 
Tüberküloz tanısında ARB mikroskobisinin duyarlılığı \%25-85 arasında değiş̧mektedir. Olgumuzda hem ileal biyopsi materyalinin hem de periton sıvısının yayma incelemesinde aside dirençli basil görülmemiştir. Bunun nedeni basil yükünün düşük olması ve mikroskopi duyarlılığının düşük olması olabilir. Tüberkülozun kesin tanısı bakterinin kültür ortamında üretilmesi ve tanımlanması esasına dayanır. M.tuberculosis'in bölünme süresi 18-24 saat olduğundan diğer bakterilere göre kültürde üremesi uzun zaman almaktadır. Katı besiyerinde üreme 42 güne kadar uzayabilirken, sıvı temelli besiyerlerinde bu süre 7-14 güne kadar düşmüştür ${ }^{13}$. Olgumuzda sıvı kültür ortamında periton sıvısı 11. günde, ileum biyopsi örneği 14. günde ve her iki örnek katı kültürde 30. günde üreme göstermiştir. Özellikle ADTB olgularında uygun örneğin moleküler yöntemlerle M.tuberculosis kompleks açısından incelenmesi daha hızlı sonuç vermesi açısından önemlidir ${ }^{13}$.

Aktuğ Demir ve arkadaşları yaptıkları çalışmada ${ }^{12}$, klinik, radyolojik ve CA-125 yüksekliği ile peritoneal karsinomatozisi taklit eden üç intra-abdominal tüberküloz olgusu sunmuştur. Olgulardan birinin periton biyopsisine ait PCR testi pozitifken diğerinin sonucu negatif olarak tespit edilmiştir. Tüberküloz olduğundan kuvvetle şüphelenilen yayma incelemesi negatif olgular ve yayma duyarlıığının düşük olduğu ADTB olgularında mikobakteriyel 16S ribozomal RNA amplifikasyonu temeline dayanan PCR yöntemi hızlı tanıda oldukça önemlidir ${ }^{13}$. Ancak testin yanlış negatif ve yanlış pozitif sonuçları olabileceğinden, mutlaka kültür ile doğrulaması yapılmalıdır. Olgumuzda hastanın tanıya yönelik olarak PCR test istemi mevcut değildi. Eğer PCR çalışılabilseydi tanı daha erken konulup tedaviye daha erken başlanabilirdi.

Mycobacterium türlerinin üreme hızı, üreme ısısı, koloni morfolojisi, pigment üretimi ve biyokimyasal özelliklerine dayalı geleneksel tanımlama yöntemleri yakın zamana kadar kullanılmaktaydı. Bu yöntemler, zahmetli ve zaman alıcı olmasının yanı sıra yanIış tanımlamalara yol açması nedeniyle günümüzde yerini moleküler yöntemlere bırakmıştır. Çok sayıda çalışma, MALDI-TOF MS'nin mikobakterileri tanımlamada etkin bir fenotipik yöntem olabileceğini göstermektedir ${ }^{14,15}$. İzolatımız, MALDI-TOF MS yöntemi ile M.tuberculosis kompleks olarak tanımlanmış ancak alt tür tayini yapılamamıştır. Çalışmamıza benzer şekilde önceki çalışmalar $\mathrm{da}^{14,16}$, bu yöntemin grup ya da kompleks tanımlamada başarılı olduğunu ancak alt türleri ayırmada yetersiz kaldığını göstermiştir. Tüberküloz dışı mikobakterilerin (TDM) tanımlanması kültür ortamı, ekstraksiyon protokolü ve veri tabanlarındaki farklılıklara göre değişmekle birlikte, bu grup mikobakteriler için MALDI-TOF MS'nin \%91-97.4 arasında tür, kompleks veya grup düzeyinde doğru sonuç verdiği tespit edilmiştir ${ }^{14-16}$.

MTBC içerisindeki alt türlerin ayrımında, türler içinde genetik çeşitliliği sağlayan farklılık bölgeleri (RDs), insersiyon sekansları (özellikle IS6110) ve özgül polimorfizmleri hedefleyen PCR tabanlı hibridizasyon ve dizi analizi gibi pek çok yöntem kullanılmakta ve geliştirilmektedir ${ }^{17}$. Ülkemizde, mikobakterinin $16 \mathrm{~S}-23 \mathrm{~S}$ ve $23 \mathrm{~S}$ rRNA'sı hedef alınarak yapılan "Line Prob Assay (LPA)" ve doğrudan tekrar (DR) lokusundaki polimorfizmlere odaklanan spoligotiplendirme yöntemleri MTBC içindeki türlerin ayrımında sıklıkla kul- 
lanılmaktadır ${ }^{18}$. Bu çalışmada MTBC alt tür tayini LPA temelli GenoType MTBC VER 1.X (Hain Lifescience, HardwiesenstraBe, Almanya) kiti ile yapıldı. Richter ve arkadaşlarının yaptıkları çalışmada ${ }^{19}$ GenoType MTBC testinin duyarlıığı \%100 olarak bulunmuştur. Yine başka bir çalışmada ${ }^{20}$ testin duyarlılığı \%93.2 ve özgüllüğü \%100 olarak tespit edilmiştir.

Sonuç olarak, üreme dönemindeki bir kadında asit, overde kitle, CA-125 yüksekliği, kilo kaybı gibi bulgular varlığında malignitenin yanında intra-abdominal tüberküloz düşünülmeli ve radikal cerrahi yapılmadan önce tanı mikrobiyolojik testlerle kesinleştirilmelidir.

\section{ÇIKAR ÇATIŞMASI}

Yazarlar bu makale ile ilgili herhangi bir çıkar çatışması bildirmemişlerdir.

\section{KAYNAKLAR}

1. World Health Organization (WHO). Global Tuberculosis Report 2020.

2. Mignard S, Pichat C, Carret G. Mycobacterium bovis infection, Lyon, France. Emerg Infect Dis 2006; 12(9): 1431-3.

3. T.C. Sağlık Bakanlığı. Tüberküloz Tanı ve Tedavi Rehberi. Ankara; 2019.

4. Bozer M, Coşkun A, Düzgün ŞA, Karaoğlanoğlu M. Abdominal tüberküloz ve klinik sunumları. Cerrahi Tıp Bil Derg 2001; 7: 194-7.

5. Koc S, Beydilli G, Tulunay G, Ocalan R, Boran N, Ozgul N, et al. Peritoneal tuberculosis mimicking advanced ovarian cancer: a retrospective review of 22 cases. GynecolOncol 2006; 103(2): 565-9.

6. Uzunköy A, Nazlıgül Y. Tüberküloz peritonit. Turkiye Klinikleri J Med Sci 2006; 26(4): 404-8.

7. Koff A, Azar MM. Diagnosing peritoneal tuberculosis. BMJ Case Rep2020; 13(2): e233131.

8. Sanai FM, Bzeizi KI. Tuberculous peritonitis presenting features, diagnostic strategies and treatment. Aliment Pharmacol Ther 2005; 22(8): 685-700.

9. Rodriguez Z, Pombo F. Peritoneal tuberculosis versus peritoneal carcinomatosis: distinction based on CT findings. J Comput Assist Tomogr 1996; 20(2): 269-72.

10. Wang H, Qu X, Liu X, Ding L, Yue Y. Female peritoneal tuberculosis with ascites, pelvic mass, or elevated CA 125 mimicking advanced ovarian cancer: a retrospective study of 26 cases. J Coll Physicians Surg Pak 2019; 29(6): 588-89.

11. Şimsek H, Savaş MC, Kadayıfçı A, Tatar G. Elevated serum CA 125 concentration in patients with tuberculous peritonitis: a case-control study. Am J Gastroenterol 1997; 92(7): 1174-6.

12. Aktuğ Demir N, Sümer Ş, Ural O, Çifci Ş, Kılınçer A. Peritoneal karsinomatozis ile başvuran intra-abdominal tüberküloz olguları. Flora 2020; 25(2): 262-8.

13. Türkiye Halk Sağlığı Kurumu Başkanlığı, Mikrobiyoloji Referans Laboratuvarları Daire Başkanlığı. Ulusal Tüberküloz Tanı Rehberi. 2014

14. Akyar I, Çavuşoğlu C, Ayaş M, Sürücüoğlu S, illki ZA, Kaya DE, et al. Evaluation of the performance of MALDI-TOF MS and DNA sequence analysis in the identification of mycobacteria species. TurkJ Med Sci 2018; 48(6): 1351-57.

15. Genc GE, Demir M, Yaman G, Kayar B, Koksal F, Satana D. Evaluation of MALDI-TOF MS for identification of nontuberculous mycobacteria isolated from clinical specimens in mycobacteria growth indicator tube medium. New Microbiol 2018; 41(3): 214-9. 
16. Body BA, Beard MA, Slechta ES, Hanson KE, Barker AP, Babady NE, et al. Evaluation of the Vitek MS v3. 0 matrix-assisted laser desorption ionization - time of flight mass spectrometry system for identification of Mycobacterium and Nocardia species. J Clin Microbiol2018; 56(6): e00237-18.

17. Elsayed MSAE, Amer A. The rapid detection and differentiation of Mycobacterium tuberculosis complex members from cattle and water buffaloes in the delta area of Egypt, using a combination of real-time and conventional PCR. Mol Bio Rep 2019; 46(4): 3909-19.

18. Çavuşoğlu C, Karaca NE, Azarsız E, Ulusoy E, Kütükçüler N. NEMO mutasyonlu bir bebekten izole edilen rifampisine dirençli Mycobacterium bovis BCG Suşu. Mikrobiyol Bul 2015; 49(2): 272-7.

19. Richter E, Weizenegger M, Fahr AM, Rüsch-Gerdes S. Usefulness of the GenoType MTBC assay for differentiating species of the Mycobacterium tuberculosis complex in cultures obtained from clinical specimens. J Clin Microbiol 2004; 42(9): 430306.

20. Somoskovi A, Dormandy J, Rivenburg J, Pedrosa M, McBride M, Salfinger M.Direct comparison of the genotype MTBC and genomic deletion assays in terms of ability to distinguish between members of the Mycobacterium tuberculosis complex in clinical isolates and in clinical specimens. J Clin Microbiol 2008; 46(5): 185457. 